\title{
Heritability of advertisement call properties of the Japanese quail
}

\author{
M. Sezer ${ }^{a *}$ (D) and A. Koçak ${ }^{b}$ (D) \\ ${ }^{a}$ Department of Bioengineering, Faculty of Engineering, Karamanoğlu Mehmetbey University, PO Box 70100, Karaman, Turkey \\ ${ }^{b}$ Department of Agricultural Biotechnology, Faculty of Agriculture, Siirt University, PO Box 56100, Siirt, Turkey \\ *e-mail: metsez@gmail.com
}

Received: June 4, 2018 - Accepted: August 27, 2018 - Distributed: February 28, 2020

(With 1 figure)

\begin{abstract}
The objective of this study was to investigate genetic variances and covariances among features of the male Japanese quail advertisement call. Duration of the first, second and third syllable, the length of interval 1 (between the first and the second syllable), interval 2 (between the second and the third syllable) and damping (extension of the third syllable) were measured as temporal properties of the call. Spectral properties were peak frequencies of each syllable and the damping component. In this study, 1730 calls were recorded from 488 male Japanese quail. The restricted maximum likelihood procedure for repeated measurements was applied to estimate (co)variance components and genetic parameters for the examined traits. Heritability estimates of call parameters of the male Japanese quail ranged from low to high values (0.04-0.65) and they were generally higher for temporal properties than for spectral properties. Among the temporal properties of the call, the highest genetic correlation was between the first and the second syllable $(0.96 \pm 0.251)$ while the lowest genetic correlation was between the first and the third syllable $(0.03 \pm 0.231)$. Significant genetic correlations were generally high and positive among peak frequencies of the syllables. Despite the lack of apparent pattern, interval lengths tended to have positive correlation with spectral properties of the call, but the correlation of syllable lengths with spectral properties of the call was negative.
\end{abstract}

Keywords: quail, genetic parameters, REML, crow.

\section{Herdabilidade de propriedades de chamada de anúncio da codorna japonesa}

\section{Resumo}

O objetivo deste estudo foi investigar as variâncias e covariâncias genéticas entre as características do canto de anúncio de codornas japonesas. A duração da primeira, segunda e terceira sílaba, o comprimento do intervalo 1 (entre a primeira e a segunda sílaba), o intervalo 2 (entre a segunda e a terceira sílaba) e o amortecimento (extensão da terceira sílaba) foram medidos como propriedades temporais da chamada. As propriedades espectrais foram as frequências de pico de cada sílaba e o componente de amortecimento. Neste estudo, 1730 chamadas foram registradas de 488 codornas japonesas masculinas. O procedimento de máxima verossimilhança restrita para medidas repetidas foi aplicado para estimar componentes de (co) variância e parâmetros genéticos para as características examinadas. As estimativas de herdabilidade dos parâmetros de chamada das codornas japonesas masculinas variaram entre valores baixos e altos $(0,04-0,65)$ e foram geralmente mais elevadas para as propriedades temporais do que para as propriedades espectrais. Dentre as propriedades temporais da chamada, a maior correlação genética foi entre a primeira e a segunda sílaba $(0,96 \pm 0,251)$, enquanto a menor correlação genética foi entre a primeira e a terceira sílaba $(0,03 \pm 0,231)$. Correlações genéticas significativas foram geralmente altas e positivas entre as frequências de pico das sílabas. Apesar da falta de padrão aparente, os comprimentos de intervalo tenderam a ter uma correlação positiva com as propriedades espectrais da chamada, mas a correlação dos comprimentos das sílabas com as propriedades espectrais da chamada foi negativa.

Palavras-chave: codorna, parâmetros genéticos, REML, corvo.

\section{Introduction}

Secondary sexual characters have an important role in species recognition, communication within and between sexes, and consequently reproduction of both domestic and wild animals. Differences in communication signals among closely related species may lead to pre-mating isolation mechanism preventing hybridisation in nature
(Anderson, 1994; Price, 1998). Genetic basis of various sexual behaviours including acoustic signals that are involved in sexual selection have been demonstrated for a wide range of species (Butlin, 1995; Bakker, 1999; Neff and Pitcher, 2005; Welch et al., 2014). Heritability predicts the response of a phenotype to selection. Low heritability 
estimates may be as a result of low additive genetic variance or high residual variance. The traits related with the condition of the courting male are expected to be sensitive to environmental factors and to have high phenotypic variation and low heritability values (Suvanto et al., 1999).

Japanese quail (Coturnix coturnix japonica) was reported to be domesticated in the 11 th century as a songbird and still lives in the wild in Asia (Cheng and Kimura, 1990). Advertisement calls of Japanese quail are composed of two short syllables followed by an extended trill that fades away with a short damping component (Guyomarc'h et al., 1998; Sezer and Tekelioglu, 2010). Frequencies of these syllables gradually increase throughout the call. The potential effect of the quail calls to the individual recognition (Guyomarc'h et al., 1998) and reproductive condition of females (Adkins-Regan, 1996; Goodson and Adkins-Regan, 1997) had been demonstrated. The influence of learning on Galliforms' call has not been reported yet and it is believed that their calls are mainly determined by the genetic constitution of the individual (Derégnaucourt et al., 2001; Derégnaucourt, 2010). On the other hand, age, reproductive status (Schleidt and Shalter, 1973; Yazaki et al., 1999) and age of sexual maturation (Sezer and Tekelioglu, 2010) were reported as factors affecting the temporal properties of the quail calls.

Despite the extensive research concerning mate choice in Japanese quail (Adkins-Regan, 1996; Mills et al., 1997; White and Galef Júnior, 2000a, b; Lumineau et al.,2005), little is known about the genetic basis of their advertisement calls. Especially, genetic parameters have not been investigated yet. The restricted maximum likelihood procedure (REML), a widely used method to estimate the variance-covariance components, allows taking into account all the pedigree information in a single model describing the whole population (Lynch and Walsh, 1998). Hence, the objective of the current study was to estimate the genetic and phenotypic parameters for advertisement call properties of male Japanese quail by REML procedure using animal model with repeated records.

\section{Material and Methods}

\subsection{Animals and housing}

The Japanese quail (Cotunix coturnix Japonica) used in this study were obtained from the population reared at the Quail Breeding Unit of Gaziosmanpaşa University,
Tokat, Turkey. All birds were initially collected among the hatchling from commercial hatcheries. Female adult birds were housed in individual stainless steel wire mesh cages for accurate pedigree identification. Parents of the next generation were chosen randomly among the consequent generation offspring. Special care was taken to avoid inbreeding. Each male was mated with two females, allowing each male to stay with a female for a day.

Egg collection was started one week after the beginning of the mating. Daily collected eggs were recorded with their sire and dame number. When the chicks hatched by artificial incubation, they were labelled with wing-rings and placed in quail battery brooders randomly. Analyses were carried out with the records of 488 quails (1730 call), the progeny of 153 sires and 198 dames in six hatching groups (generation). Numbers of recorded males in each generation were $77,89,100,99,54$ and 69 , respectively.

Birds were housed for the first three weeks at 24 hours lighting, following weeks at 16:8 light:dark cycle. The temperature started at $36^{\circ} \mathrm{C}$. Temperature was decreased by $3{ }^{\circ} \mathrm{C}$ every week until it reached $24^{\circ} \mathrm{C}$. Birds were allowed ad libitum access to food and water. They were fed with $240 \mathrm{~g} / \mathrm{kg}$ crude protein $(\mathrm{CP})$ and $13.39 \mathrm{MJ} \mathrm{ME} / \mathrm{kg}$ starter diet for 21 days, $190 \mathrm{~g} / \mathrm{kg} \mathrm{CP}$ and $12.55 \mathrm{MJ} \mathrm{ME} / \mathrm{kg}$ grower diet between 22 and 35 days of age and thereafter $170 \mathrm{~g} / \mathrm{kg}$ $\mathrm{CP}$ and $11.50 \mathrm{MJ} \mathrm{ME} / \mathrm{kg}$ breeder diet. Birds were kept in mixed gender groups of 15 to 20 individuals to allow the males have physical interactions with other individuals.

\subsection{Recording and song properties}

Advertisement calls were recorded when the males were completely sexually mature, as testified by the development of the proctodeal gland with foam production (Mohan et al., 2002; Marin and Satterlee, 2004). Males were placed in a sound-proof chamber $(1 \times 1.5 \times 0.5 \mathrm{~m})$ for a period of five minutes and calls were recorded with a personal computer (sampling rate $=32 \mathrm{kHz}$, frequency resolution $=7.8 \mathrm{~Hz}$, time resolution=128 $\mathrm{ms}$ ) equipped with a Sennheiser MD 41 dynamic microphone. When recording of a male call (3-5 calls from each male) was unsuccessful, the procedure was repeated two days after the first attempt. All males were recorded within two weeks after the recording process was started.

Japanese quail's calls are composed of three parts (Figure 1); two short syllables followed by an extended trill that fades away with a short component called 'damping'.

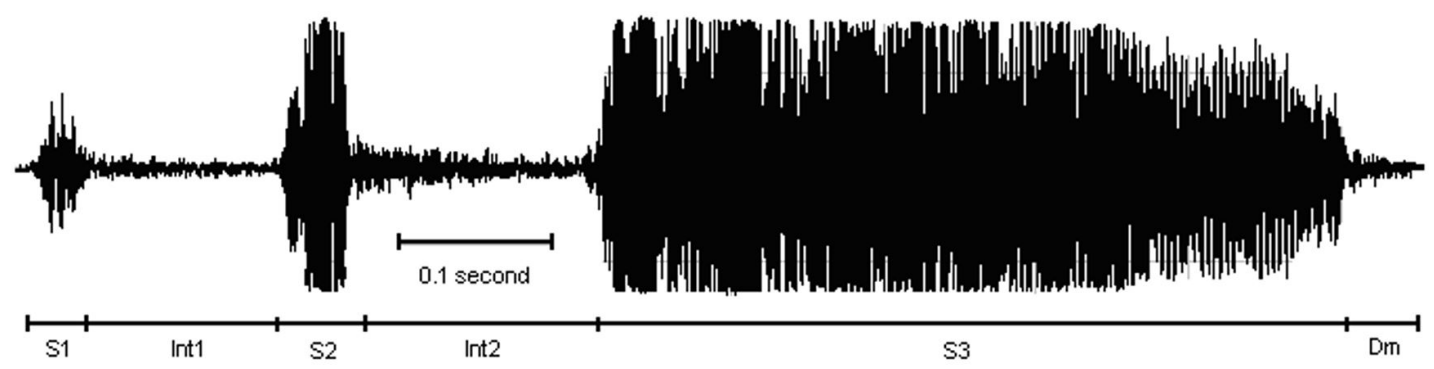

Figure 1. Oscillogram of a male Japanese quail call. S1, Int1, S2, Int2, S3 and Dm are the lengths of the first syllable, interval one, the second syllable, interval two, the third syllable and damping, respectively. 
Hence each recorded calls of Japanese quail were analysed to measure syllable (S1, S2 and S3), interval (Int1, Int2) and damping $(\mathrm{Dm})$ durations and peak frequencies of each syllables (Fr1, Fr2, Fr3) and damping (FrD) component. The peak frequency displays the frequency of the strongest spectral component in the selected syllable.

\subsection{Analyses}

Variance components and genetic parameters were estimated using REML with repeated measurements (ASREML software; Gilmour et al., 2000).Genetic and phenotypic correlations between traits were estimated in two trait analyses. For each trait, hatching group was included as a fixed effect in the animal model. Animal was fitted as random in the model to estimate direct additive genetic variance.

\section{Results}

The statistical description of the call properties is summarized in Table 1. Although rearing and recording conditions were identical, significant differences $(\mathrm{P}<0.05)$ were observed in call parameters among hatching groups (generations). This effect did not show any trend throughout the study for any of the examined traits. Hence, the effect of generation might be caused by the genetic structure of the parents used in each generation.

REML estimates of heritability as well as genetic and phenotypic correlations between call properties were shown in Table 2. Generally, temporal properties had higher heritability values than spectral properties. Among the temporal properties, the highest heritability estimated for Int $1(0.65 \pm 0.123)$ and the lowest for Int2 $(0.16 \pm 0.084)$. Heritability estimate of the third syllable $(0.43 \pm 0.107)$ was the highest among syllable length, followed by the heritability of the first $(0.35 \pm 0.114)$ and the second syllable $(0.18 \pm 0.103)$. Heritability of the spectral properties of the call was low and ranged between 0.04 and 0.17 .

Response to selection does not only depend on the genetic variation found in a trait, but also on the genetic correlation among the selected traits (Lande and Arnold, 1983). The pattern of genetic correlations between $\mathrm{S} 1$ and Int1 and between S1 and Int2 were high-positive and low-negative, respectively. Interestingly, genetic correlations between $\mathrm{S} 2$ and Int 1 and between $\mathrm{S} 2$ and Int 2 were low-positive and high-negative. The highest genetic correlation was between S1 and S2 while the lowest genetic correlation was between S1 and S3. Moderate negative genetic correlation was observed between S2 and S3. Generally, high positive genetic correlations were observed

Table 1. Mean \pm standard deviation, and number of observation (in branched) of the examined advertisement call properties within generation.

\begin{tabular}{|c|c|c|c|c|c|c|c|c|c|c|}
\hline Generation & $\begin{array}{l}\text { Int1 } \\
(\mathrm{ms})\end{array}$ & $\begin{array}{l}\text { Int2 } \\
\text { (ms) }\end{array}$ & $\begin{array}{c}\text { S1 } \\
(\mathrm{ms})\end{array}$ & $\begin{array}{l}\text { S2 } \\
(\mathrm{ms})\end{array}$ & $\begin{array}{c}\text { S3 } \\
(\mathrm{ms})\end{array}$ & $\begin{array}{c}\text { Dm } \\
(\mathrm{ms})\end{array}$ & $\begin{array}{c}\text { Fr1 } \\
(\mathrm{Hz})\end{array}$ & $\begin{array}{l}\text { Fr2 } \\
(\mathrm{Hz})\end{array}$ & $\begin{array}{c}\text { Fr3 } \\
(\mathrm{Hz})\end{array}$ & $\begin{array}{l}\text { FrD } \\
(\mathrm{Hz})\end{array}$ \\
\hline $\begin{array}{c}1 \\
(77)\end{array}$ & (73 & (76 & (73 & $\begin{array}{c}65.5 \pm 27.12 \\
(76)\end{array}$ & $\begin{array}{c}579.0 \pm 149.1 \\
\text { (77) }\end{array}$ & $\begin{array}{c}130.5 \pm 44.19 \\
(77)\end{array}$ & $\begin{array}{c}1719 \pm 256.2 \\
(67)\end{array}$ & $\begin{array}{c}1963 \pm 312.3 \\
(75)\end{array}$ & $\begin{array}{c}2133 \pm 411.6 \\
(77)\end{array}$ & $\begin{array}{c}2438 \pm 546.0 \\
(77)\end{array}$ \\
\hline $\begin{array}{c}2 \\
(89)\end{array}$ & (81 & $\begin{array}{r}106.0 \pm 3 \\
(88\end{array}$ & $\begin{array}{r}.7 \pm 1 \\
(81\end{array}$ & $\begin{array}{c}102.9 \pm 29.38 \\
(88)\end{array}$ & $\begin{array}{c}651.5 \pm 91.2 \\
(89)\end{array}$ & 5.65 & $\begin{array}{c}1695 \pm 190.6 \\
(80)\end{array}$ & $\begin{array}{c}1947 \pm 334.4 \\
(87)\end{array}$ & $\begin{array}{c}2124 \pm 475.3 \\
(87)\end{array}$ & $\begin{array}{c}2354 \pm 546.1 \\
(86)\end{array}$ \\
\hline 3 & (90 & (97 & 5.13 & $\begin{array}{c}64.9 \pm 21.10 \\
(97)\end{array}$ & $\begin{array}{c}442.0 \pm 98.9 \\
\quad(100)\end{array}$ & $\begin{array}{l}4.23 \\
9)\end{array}$ & $\begin{array}{c}1711 \pm 209.6 \\
\quad(83)\end{array}$ & $\begin{array}{c}2002 \pm 294.2 \\
\quad(87)\end{array}$ & $\begin{array}{c}2164 \pm 323.4 \\
(100)\end{array}$ & $\begin{array}{l}2301 \pm 440.1 \\
\quad(93)\end{array}$ \\
\hline $\begin{array}{c}4 \\
(99)\end{array}$ & $\begin{array}{r}63.4 \pm 2 \\
\quad(79\end{array}$ & $\begin{array}{r}124.0 \pm \\
(89\end{array}$ & $\begin{array}{c}63.8 \pm 12.25 \\
(79)\end{array}$ & $\begin{array}{c}65.1 \pm 19.03 \\
(89)\end{array}$ & $\begin{array}{c}437.9 \pm 109.0 \\
\text { (99) }\end{array}$ & $\begin{array}{r}81.2 \pm 1 \\
\quad(99\end{array}$ & $\begin{array}{c}1752 \pm 224.1 \\
\quad(70)\end{array}$ & $\begin{array}{c}2070 \pm 328.2 \\
\quad(79)\end{array}$ & $\begin{array}{c}2193 \pm 292.0 \\
(97)\end{array}$ & $\begin{array}{c}2323 \pm 488.3 \\
(85)\end{array}$ \\
\hline $\begin{array}{c}5 \\
(54)\end{array}$ & $\begin{array}{c}60.5 \pm 26.44 \\
\quad(53)\end{array}$ & $\begin{array}{l}119.9 \pm 34.03 \\
(54)\end{array}$ & $\begin{array}{c}65.4 \pm 15.83 \\
\quad(53)\end{array}$ & $\begin{array}{c}73.3 \pm 29.68 \\
(54)\end{array}$ & $\begin{array}{c}422.3 \pm 81.1 \\
(54)\end{array}$ & $\begin{array}{c}85.0 \pm 31.36 \\
(54)\end{array}$ & $\begin{array}{c}1702 \pm 328.1 \\
(50)\end{array}$ & $\begin{array}{c}2050 \pm 264.4 \\
\quad(52)\end{array}$ & $\begin{array}{c}2200 \pm 286.7 \\
\quad(54)\end{array}$ & $\begin{array}{c}2565 \pm 138.5 \\
(54)\end{array}$ \\
\hline $\begin{array}{c}6 \\
(69)\end{array}$ & $\begin{array}{c}67.2 \pm 31.44 \\
(59)\end{array}$ & $\begin{array}{c}130.0 \pm 44.50 \\
(68)\end{array}$ & $\begin{array}{c}67.4 \pm 19.57 \\
(59)\end{array}$ & $\begin{array}{c}66.8 \pm 30.05 \\
(68)\end{array}$ & $\begin{array}{l}445.7 \pm 101.1 \\
\quad(69)\end{array}$ & $\begin{array}{c}72.1 \pm 31.49 \\
(69)\end{array}$ & $\begin{array}{c}1785 \pm 159.2 \\
\quad(58)\end{array}$ & $\begin{array}{c}2109 \pm 388.5 \\
\quad(68)\end{array}$ & $\begin{array}{c}2132 \pm 314.4 \\
\quad(69)\end{array}$ & $\begin{array}{c}2570 \pm 315.7 \\
(67)\end{array}$ \\
\hline $\begin{array}{l}\text { Total } \\
(488)\end{array}$ & $\begin{array}{c}59.2 \pm 29.67 \\
(435)\end{array}$ & $\begin{array}{c}117.8 \pm 44.51 \\
(432)\end{array}$ & $\begin{array}{c}64.9 \pm 20.29 \\
(435)\end{array}$ & $\begin{array}{c}73.4 \pm 29.74 \\
(472)\end{array}$ & $\begin{array}{c}499.3 \pm 146.2 \\
\quad(488)\end{array}$ & $\begin{array}{c}99.8 \pm 49.79 \\
(488)\end{array}$ & $\begin{array}{c}1726 \pm 217.9 \\
(408)\end{array}$ & $\begin{array}{c}2019 \pm 340.4 \\
(448)\end{array}$ & $\begin{array}{c}2158 \pm 381.8 \\
(484)\end{array}$ & $\begin{array}{c}2408 \pm 503.0 \\
\quad(462)\end{array}$ \\
\hline
\end{tabular}

Table 2. Genetic and phenotypic parameters for measured characteristics of Japanese quail calls. Heritability on diagonal, genetic correlations above and phenotypic correlations below the diagonal with their standard errors.

\begin{tabular}{|c|c|c|c|c|c|c|c|c|c|c|}
\hline & Int1 & Int2 & S1 & S2 & S3 & Dm & Fr1 & Fr2 & Fr3 & FrD \\
\hline Int1 & $0.65 \pm 0.123$ & $0.32 \pm 0.292$ & $0.53 \pm 0.196$ & $0.25 \pm 0.305$ & $-0.03 \pm 0.194$ & $-0.21 \pm 0.216$ & $0.08 \pm 0.338$ & $0.05 \pm 0.466$ & $0.24 \pm 0.222$ & $0.43 \pm 0.210$ \\
\hline Int2 & $0.01 \pm 0.059$ & $0.16 \pm 0.084$ & $-0.19 \pm 0.320$ & $-0.59 \pm 0.367$ & $0.04 \pm 0.286$ & $-0.74 \pm 0.329$ & $-0.09 \pm 0.456$ & $0.02 \pm 0.614$ & $-0.03 \pm 0.341$ & $0.45 \pm 0.332$ \\
\hline $\mathrm{S} 1$ & $-0.02 \pm 0.058$ & $-0.26 \pm 0.052$ & $0.35 \pm 0.114$ & $0.96 \pm 0.251$ & $0.03 \pm 0.231$ & $-0.07 \pm 0.261$ & $0.28 \pm 0.376$ & $-0.18 \pm 0.522$ & $-0.31 \pm 0.282$ & $0.14 \pm 0.300$ \\
\hline $\mathrm{S} 2$ & $-0.22 \pm 0.057$ & $-0.12 \pm 0.048$ & $0.24 \pm 0.052$ & $0.18 \pm 0.103$ & $-0.25 \pm 0.276$ & $-0.04 \pm 0.320$ & $-0.14 \pm 0.327$ & $0.36 \pm 0.672$ & $-0.02 \pm 0.349$ & $-0.29 \pm 0.371$ \\
\hline S3 & $-0.12 \pm 0.058$ & $-0.08 \pm 0.051$ & $0.05 \pm 0.054$ & $0.08 \pm 0.052$ & $0.43 \pm 0.107$ & $0.30 \pm 0.213$ & $-0.16 \pm 0.330$ & $-0.57 \pm 0.481$ & $-0.50 \pm 0.238$ & $-0.18 \pm 0.263$ \\
\hline Dm & $-0.14 \pm 0.053$ & $-0.12 \pm 0.046$ & $0.03 \pm 0.050$ & $0.19 \pm 0.046$ & $0.40 \pm 0.042$ & $0.26 \pm 0.093$ & $-0.53 \pm 0.442$ & $0.14 \pm 0.549$ & $-0.62 \pm 0.211$ & $-0.41 \pm 0.274$ \\
\hline Fr1 & $0.03 \pm 0.053$ & $0.05 \pm 0.054$ & $0.04 \pm 0.049$ & $-0.08 \pm 0.043$ & $-0.23 \pm 0.048$ & $-0.20 \pm 0.044$ & $0.12 \pm 0.095$ & $0.10 \pm 0.847$ & $0.84 \pm 0.467$ & $0.89+0.308$ \\
\hline Fr2 & $0.13 \pm 0.048$ & $0.02 \pm 0.044$ & $-0.13 \pm 0.045$ & $-0.09 \pm 0.044$ & $-0.20 \pm 0.044$ & $-0.19 \pm 0.041$ & $0.22 \pm 0.041$ & $0.04 \pm 0.063$ & $-0.03+0.466$ & $-0.51 \pm 0.715$ \\
\hline Fr3 & $0.10 \pm 0.051$ & $0.10 \pm 0.045$ & $-0.03 \pm 0.048$ & $-0.13 \pm 0.045$ & $-0.25 \pm 0.044$ & $-0.38 \pm 0.037$ & $0.22 \pm 0.043$ & $0.28+0.038$ & $0.17 \pm 0.071$ & $0.64 \pm 0.257$ \\
\hline FrD & $0.13 \pm 0.040$ & $0.14 \pm 0.036$ & $0.03 \pm 0.038$ & $-0.03 \pm 0.036$ & $-0.03 \pm 0.037$ & $-0.13 \pm 0.034$ & $0.09+0.037$ & $0.11 \pm 0.033$ & $0.21 \pm 0.032$ & $0.11 \pm 0.052$ \\
\hline
\end{tabular}


among peak frequencies of the syllables. Exceptionally, genetic correlation was moderately negative between Fr2 and FrD and lowly positive between Fr1 and Fr2. Despite the lack of apparent pattern, interval lengths tended to be positively and syllable lengths negatively correlated with spectral properties of the call. Negative phenotypic correlations between intervals and syllable lengths and positive correlations among syllable lengths were observed. Phenotypic correlations between peak frequencies and durations of the song properties were not strong.

\section{Discussion}

The traits related to mate choice are expected to reflect the condition of the courting male. Hence, these kinds of traits often show high phenotypic variation and may be sensitive to environmental factors (Fisher, 1958; Falconer and Mackay, 1996; Suvanto et al., 1999). The averaged heritability $( \pm \mathrm{SD})$ was reported as $0.58 \pm 0.26$ in a review of the heritability of sexually selected traits for 30 species, $60 \%$ of which were invertebrates (Pomiankowski and Møller, 1995). This high heritability values were criticised and suggested to be a publication bias because seven of those high estimations were based on relatively few data (Bakker, 1999). The data set used in this study was large compared to previous studies. On the other hand, RELM procedure is a flexible and efficient way to estimate the genetic and phenotypic parameters, especially when selection is occurring in the population (Gianola and Fernando, 1986). Additionally, RELM heritability estimates are free from bias of overestimation arise from non-additive genetic variance such as dominance and epistasis. Hence, it could be expected to obtain slightly lover heritability in this study than the previous heritability reports.

The heritability of call properties reported in this study was also low relative to the other quantitative characters of Japanese quail, e.g. weekly live weight and age of sexual maturation (Resende et al., 2005; Sezer, 2007). However, most of the advertisement call properties of Japanese quail appear to be genetically variable enough to allow effective selection. The main reason for lower heritability estimates of the spectral properties is due to rather low additive genetic and high residual variation as compared with the corresponding estimated variance components for temporal properties. Among the temporal properties, the second interval and the second syllable had lower heritability estimates than other temporal call properties. The traits that had low heritability estimated in the present study could be thought as closely related with fitness. On the other hand, the duration of the first interval, the first and the third syllables had high heritability estimates, indicating their potential to be used as morphological characters.

Advertisement calls of the Japanese quail contain the information about species-specific and individual identity of the caller (Guyomarc'h et al., 1998). Like in most species of songbirds (Catchpole and Slater, 1995), male mating calls of quail play a crucial role in female mate choice (Guyomarc'h et al., 1998; Goodson and Adkins-Regan,
1997). Female preferences for attractive male calls can be favoured by the indirect benefit of having attractive male offspring. This could be true when the phenotypic variation in sexually selected traits has a large additive component as found in this study. However, it is not clear which components of the male call have preferred by the females. Additionally, there is no information of how many distinct characteristics of call involved in recognition. Hence, genetic variation needed for response to selection that depends on specificity of the female preferences do not imply that rapid evolution of call properties is possible. Future research on female mate choice is required to determine the influence of variation in call parameters.

\section{References}

ADKINS-REGAN, E., 1996. Neuro anatomy of sexual behavior in the male Japanese quail from top to bottom. Poultry and Avian Biology Reviews, vol. 7, pp. 193-204.

ANDERSON, M., 1994. Sexual selection. 1. ed. New Jersey: Princeton University Pres.

BAKKER, T.C.M., 1999. The study of intersexual selection using quantitative genetics. Behaviour, vol. 136, no. 9, pp. 1237-1266. http://dx.doi.org/10.1163/156853999501748.

BUTLIN, R.K., 1995. Genetic variation in mating signals and responses. In: D.M. LAMBERT, H.G. SPENCER, eds. Speciation and the recognition concept: Theory and application. London: The Johns Hopkins University Press, pp. 327-366.

CATCHPOLE, C.K. and SLATER, P.J.B., 1995. Sexual selection and female choice. In: C.K. CATCHPOLE, P.J.B. SLATER, eds. Bird Song. Cambridge: Cambridge University Press, pp. 139-158.

CHENG, K.M. and KIMURA, M.1990. Mutations and major variants in Japanese quail. In: R.D. CRAWFORD, eds. Poultry Breeding and Genetics. New York: Elsevier Science Publishing Co., pp. 333-362.

DERÉGNAUCOURT, S., 2010. Interspecific hybridization as a tool to understand vocal divergence: the example of crowing in quail (Genus Coturnix). PLoSOne, vol. 5, no. 2, pp. e9451. http://dx.doi.org/10.1371/journal.pone.0009451.PMid:20195481.

DERÉGNAUCOURT, S., GUYOMARC'H, J. and RICHARD, V., 2001. Classification of hybrid crows in quail using artificial neural networks. Behavioural Processes, vol. 56, no. 2, pp. 103-112. http://dx.doi.org/10.1016/S0376-6357(01)00188-7. PMid:11672936.

FALCONER, D.S. and MACKAY, T.F.C., 1996. Introduction to Quantitative Genetics. 4th ed. London: Longman.

FISHER, R.A., 1958. The genetical theory of natural selection. 2nd ed. New York: Dover.

GİANOLA, D.andFERNANDO, R.L., 1986. Bayesian methods in animal breeding theory. Journal of Animal Science, vol. 63, no. 1, pp. 217-244. http://dx.doi.org/10.2527/jas1986.631217x.

GILMOUR, A.R., CULLIS, B.R., WELHAM, S.J. and THOMPSON, R., 2000. ASREML. Australia: NSW Agriculture.

GOODSON, J.L. and ADKINS-REGAN, E., 1997. Playback of crows of male Japanese quail elicits female phonotaxis. The Condor, vol. 99, no. 4, pp. 990-993. http://dx.doi.org/10.2307/1370153. 
GUYOMARC'H, J.-C., AUPIAIS, A. and GUYOMARC'H, C., 1998. Individual differences in the long-distance vocalizations used during pair bonding in European quail (Coturnixcoturnix). Ethology Ecology and Evolution, vol. 10, no. 4, pp. 333-346. http://dx.doi.org/10.1080/08927014.1998.9522847.

LANDE, R. and ARNOLD, S.J., 1983. The measurement of selection on correlated characters. Evolution; International Journal of Organic Evolution, vol. 37, no. 6, pp. 1210-1226. http://dx.doi. org/10.1111/j.1558-5646.1983.tb00236.x. PMid:28556011.

LUMINEAU, S., HOUDELIER, C. and GUYOMARC'H, C., 2005. Individual differences in sexual display behaviour in the male Japanese quail. Ethology Ecology and Evolution, vol. 17, no. 2, pp. 121-134. http://dx.doi.org/10.1080/08927014.2005.9522602.

LYNCH, M. and WALSH, B., 1998. Genetics and Analysis of Quantitative Traits. 1st ed. Sunderland: Sinauer.

MARIN, R.H. and SATTERLEE, D.G., 2004. Clocal gland and testes development in male Japanese quail selected for divergent adreno cortical responsiveness. Poultry Science, vol. 83, no. 6, pp. 1028-1034. http://dx.doi.org/10.1093/ps/83.6.1028. PMid:15206632.

MILLS, A.D., CRAWFORD, L.L., DOMJAN, M. and FAURE, J.M., 1997. The behavior of the Japanese or domestic quail (Coturnix japonica). Neuroscience and Biobehavioral Reviews, vol. 21 , no. 3, pp. 261-281. http://dx.doi.org/10.1016/S01497634(96)00028-0. PMid:9168263.

MOHAN, J., MOUDGAL, R.P., SASTRY, K.V.H., TYAGI, J. and SINGH, R., 2002. Effects of hemicastration and castration on foam production and its relationship with fertility in male Japanese quail. Theriogenology, vol. 58, no. 1, pp. 29-39. http:// dx.doi.org/10.1016/S0093-691X(02)00863-4. PMid:12182362.

NEFF, B.D. and PITCHER, T.E., 2005. Genetic quality and sexual selection: an integrated framework for good genes and compatible genes. Molecular Ecology, vol. 14, no. 1, pp. 19-38. http://dx.doi. org/10.1111/j.1365-294X.2004.02395.x.PMid:15643948.

POMIANKOWSKI, A.N. and MØLLER, A.P., 1995. A resolution of the lek paradox. Proceedings. Biological Sciences, vol. 260, no. 1357, pp. 21-29. http://dx.doi.org/10.1098/rspb.1995.0054.

PRICE, T., 1998. Sexual selection and natural selection in bird speciation. Philosophical Transactions of the Royal Society of London. Series B, Biological Sciences, vol. 353, no. 1366, pp. 251-260. http://dx.doi.org/10.1098/rstb.1998.0207.
RESENDE, R.O., MARTINS, E.N., GEORG, P.C., PAIVA, E., CONTI, A.C.M., SANTOS, A.I., SAKAGUTI, E.S. and MURAKAMI, A.E., 2005. Variance components for body weight in Japanese quails (Coturnix japonica). Brazilian Journal of Poultry Science, vol. 7, no. 1, pp. 23-25. http://dx.doi.org/10.1590/ S1516-635X2005000100004.

SCHLEIDT, W.M. and SHALTER, M.D., 1973. Stereotypy of a fixed action pattern during ontogeny in Coturnix coturnixcoturnix. ZeitschriftfürTierpsychologie, vol. 33, no. 1, pp. 35-37. http:// dx.doi.org/10.1111/j.1439-0310.1973.tb02082.x. PMid:4799432 .

SEZER, M., 2007. Genetic parameters estimated for sexual maturity and weekly live weights of Japanese quail (Coturnix coturnix japonica). Asian-Australasian Journal of Animal Sciences, vol. 20, no. 1, pp. 19-24. http://dx.doi.org/10.5713/ajas.2007.19.

SEZER, M. and TEKELIOGLU, O., 2010. Variation in advertisement call properties of the Japanese quail. Pakistan Journal of Zoology, vol. 42, no. 5, pp. 581-586.

SUVANTO, L., LIIMATAINEN, J.O. and HOIKKALA, A., 1999. Variability and evolvability of male song characters in Drosophila montana populations. Hereditas, vol. 130, no. 1, pp. 13-18. http://dx.doi.org/10.1111/j.1601-5223.1999.00013.x. PMid:10364824

WELCH, A.M., SMITH, M.J. and GERHARDT, H.C., 2014. A multivariate analysis of genetic variation in the advertisement call of the gray treefrog, Hyla versicolor. Evolution, vol. 68, no. 6, pp. 1629-1639. http://dx.doi.org/10.1111/evo.12397. PMid:24621402.

WHİTE, D.J. and GALEF JÚNIOR, B.G., 2000a. Culture' in quail: social influences on mate choice of female Coturnix japonica. Animal Behaviour, vol. 59, no. 5, pp. 975-979. http:// dx.doi.org/10.1006/anbe.1999.1402. PMid:10860524.

WHİTE, D.J. and GALEF JÚNIOR, B.G., 2000b. Differences between the sexes in direction and duration of response to seeing a potential sex partner mate with another. Animal Behaviour, vol. 59, no. 6, pp. 1235-1240. http://dx.doi.org/10.1006/anbe.1999.1431. PMid:10877903.

YAZAKI, Y., MATSUSHIMA, T. and AOKI, K., 1999. Testosterone modulates stimulation-induced calling behavior in Japanese quails. Journal of Comparative Physiology. A, Neuroethology, Sensory, Neural, and Behavioral Physiology, vol. 184, no. 1, pp. 13-19. http://dx.doi.org/10.1007/s003590050302. PMid:10077861. 